ПИЛИПчУк н.П.

\title{
КОНСТИТУЦІЙНЕ ПРАВО НА ВІДПОЧИНОК У ПОЛЬЩІ: НАПРЯМИ ЗАПОЗИЧЕННЯ В УКРАЇНУ
}

У статті проаналізовано специфіку змісту конституційного права на відпочинок у Польщі. Деталізовано особливості цього виду права. Охарактеризовано значення конституційних положень польського законодавства. Сформульовано напрями запозичення позитивного досвіду в Україну.

3'ясовано необхідність удосконалення національного законодавства Польщі шляхом запозичення, яке має відбуватися щодо встановлення більшого переліку видів права на відпочинок на рівні саме Конституції. Слід наголосити на тому, що не обов'язковим є їх об'єднання в межах однієї норми, адже для кращого втілення права на відпочинок необхідним $є$ його поєднання з іншими конституційними правами, що відображають призначення такого відпочинку. Отже, ч. 1 ст. 45 Конституції України варто подати в такій редакції: «працівник має право на відпочинок у формі щорічних відпусток та додаткових відпусток, щотижневого безперервного відпочинку та щоденного безперервного відпочинку».

Визначено, що відпочинок у святкові та вихідні дні забезпечується Кабінетом Міністрів України. Також ст. 46 Конституції України варто доповнити ч. 3, відповідно до якої «кожен, хто працює, має право на соціальну відпустку у разі настання передбачених законом випадків. Держава зобов'язана гарантувати реалізацію права на соціальні відпустки». Такі конституційні зміни допомагають зробити реалізацію права на відпочинок більш конкретною та зрозуміти, які завдання стоять перед кожним конкретним органом влади.

Відзначено, що відмінністю врегулювання права на відпочинок у Польщі є визначення спеціальних норм не в окремих підзаконних актах, а у загальному порядку.

Зроблено висновок про те, що Кабінет Міністрів зобов'язаний здійснювати нагляд та контроль за втіленням права на відпочинок. Водночас для забезпечення соціальних відпусток як особливого виду права на відпочинок встановлюється значно більше право держави на втручання в суспільні відносини, отже, використання інших методів. Закріплення таких положень на конституційному рівні робить їх правовими та усуває потребу у постійному підтвердженні з боку Конституційного суду щодо відповідності нормам чи судам загальної юрисдикції правомірності дій державних органів.

Ключові слова: проблеми реалізації права, конституційне право, людина й громадянин, право на відпочинок, конститучія.

The article analyzes the specifics of the content of the constitutional right to rest in Poland. Features of this type of law are detailed. The significance of the constitutional provisions of Polish legislation is described. The directions of borrowing a positive experience in Ukraine are formulated. The need to improve Poland's national legislation through borrowing has to be clarified in order to establish a greater list of types of right to rest at the level of the Constitution itself. It should be emphasized that it is not obligatory to combine them within the same norm, because for better realization of the right to rest it is necessary to combine it with other constitutional rights that reflect the purpose of such rest. That is, Part 1 of Art. 45 of the Constitution of Ukraine should be submitted in the following editions: "the employee has the right to rest in the form of: annual holidays and additional holidays, weekly continuous rest and daily continuous rest". It is determined that the holidays in the holidays and weekends are provided by the Cabinet of Ministers

( ) ПИЛИПЧУК Н.П. - аспірантка (Інститут держави і права імені В.М. Корецького Національної академії наук України) 
of Ukraine. Also Art. 46 of the Constitution of Ukraine should be supplemented by part 3 according to which "everyone who works has the right to a social leave in the event of cases provided by law. The state is obliged to guarantee the exercise of the right to social holidays". Such constitutional changes help to make the exercise of the right to rest more specific and understand what the tasks of each authority are. It is noted that the difference in the regulation of the right to rest in Poland lies in the definition of special rules not in separate by-laws, but in the general order. It is concluded that the Cabinet of Ministers is obliged to supervise and control the implementation of the right to rest. At the same time, a much greater right of the state to intervene in public relations, and therefore to use other methods, is established as a special type of right to rest. The adoption of such provisions at the constitutional level makes it legal and eliminates the need for constant confirmation by the Constitutional Court of the conformity of a rule or of a general court with respect to the lawfulness of actions of public bodies.

Key words: problems of implementation of law, constitutional law, man and citizen, right to rest, constitution.

Вступ. Конституційне регулювання має загальний характер, що забезпечує охоплення максимально широкого кола суспільних відносин. Проте аналіз конституційного та законодавчого закріплення права на відпочинок свідчить про те, що належного рівня деталізації та визначення способів реалізації відпочинку залежно від виду та напряму діяльності не передбачено. Саме тому необхідно з'ясувати, які норми щодо права на відпочинок доречно та більш доцільно закріпити на конституційному рівні, а які варто залишити задля постійного вдосконалення та видозмінення.

Постановка завдання. Оскільки країни - учасниці ЄС мають розвинену економічну систему, що перш за все залежить від вдалого правового регулювання відносин щодо реалізації конституційного права на працю та ведення соціальної політики, то дослідження їх законодавчого досвіду у питаннях конституційного права на відпочинок дасть можливість визначити як можливі негативні аспекти реформ, так і способи їх подолання, а також й з'ясувати можливість запозичення новітніх методів правового регулювання та юридичної техніки для національного законодавства.

Питання зарубіжного досвіду та можливостей до його запозичення в Україну є малодослідженим, окремими його питаннями займались такі вчені, як К.С. Борисова, Т.В. Гавронська, Л.П. Гаращенко, С.Ф. Гуцу, К.І. Дмітрієва, В.М. Завгородня, М.І. Іншин, Л.М. Корольчук, В.Л. Костюк, С.В. Краснов, П.М. Петровський, О.А. Ситницька, В.В. Собченко, В.В. Тіщенко, О.В. Турата, В.А. Урбанович, В.В. Хромей, I.М. Хуторян.

Результати дослідження. Перш за все питання реалізації права на відпочинок частково охоплюється ст. 65 Конституції Польщі, відповідно до якої «обов'язок працювати може бути передбачений тільки законом; постійна трудова зайнятість дітей віком до 16 років забороняється; форми і характер припустимої трудової зайнятості визначаються законом» [1]. 3 цього твердження вже можна зрозуміти, що існують обмеження робочого часу саме задля гарантування права на відпочинок. Крім того, існує диференціація цього права залежно від віку суб'єкта. Однак спірним $\epsilon$ положення щодо примусової праці та обов'язку працювати, оскільки вони суперечать позиції про свободу вибору місця праці, часу її здійснення та, власне, можливості самостійно вибирати час відпочинку. Отже, конституційні права на працю та відпочинок стають менш захищеними через можливість передбачення зобов'язання працювати. Хоча сьогодні цей обов'язок не визначений польським законодавством, однак процедура його зміни є значно швидшою саме через конституційні положення.

Також право на відпочинок визначається ст. 66 Конституції Польщі щодо умов праці, де ч. 2 закріплює, що «працівник має право на передбачені законом дні щотижневого відпочинку і щорічні оплачувані відпустки; максимальні норми робочого часу визначаються законом» [1]. Отже, на відміну від української конституції, яка гарантує існування лише щорічних відпусток, конституційне право на відпочинок у Польщі гарантується також щотижневим відпочинком. Важливим є конституційне визначення оплати як обов'язкової ознаки відпусток, отже, забезпечення хоча б однієї такої відпустки на рік. Слід наголосити на тому, що оскільки ця норма права закріплена саме на рівні Конституції, то іії зміна має ускладнений характер, отже, незалежно від формулювання законодавчих актів здійснювати захист права на відпочинок можна саме з посиланням на Конституцію. 
Оскільки конституційне право на відпочинок можна тлумачити як час, проведений поза виконанням трудових обов'язків, то стає зрозуміло, що цей час використовується не лише на відновлення фізичних та психологічних сил, але й для виконання інших суспільних обов'язків. Відповідно до ст. 71 Конституції Польщі «держава у своїй соціальній та економічній політиці враховує інтереси сім'ї. Мати до і після народження дитини має право на особливу допомогу з боку публічних влад, обсяг якої визначається законом» [1]. Оскільки визначений обов'язок держави має максимально сприяти сімейним відносинам, то в межах конституційного права на відпочинок це означає забезпечення та захист достатньої тривалості відпусток як до, так і після пологів. Крім того, жінка має можливість скороченого або неповного робочого дня, а також достатню кількість перерв. Водночас формулювання «особлива допомога» свідчить про необмеженість застосування правових засобів, отже, фактично дає змогу урізноманітнити реалізацію конституційного права на відпочинок для працівників-жінок.

Звертаючись уже до Трудового кодексу Польщі, відзначаємо, що конституційне право на працю регулюється окремою главою. Слід зазначити, що значна частина норм права є аналогічною українським, проте наявні зміни свідчать саме про впровадження європейських стандартів. Так, відповідно до ст. 132 Трудового кодексу, «працівник має право на не менше ніж 11 годин безперебійного відпочинку кожен день. Положення ч. 1 не поширюється на: 1) працівників, які керують робочим місцем від імені роботодавця; 2) випадки необхідності проведення рятувальної операції для захисту життя чи здоров'я людини, захисту власності чи довкілля. У випадках, зазначених у ч. 2, працівник має право на відпочинок, еквівалентний періоду праці» [2]. Таким чином, визначено не лише максимальну тривалість робочого дня, але й мінімальну тривалість відпочинку. Така ситуація дає змогу забезпечувати реалізацію конституційного права на відпочинок через унеможливлення отримання додаткових навантажень чи роботи за сумісництвом. Проте задля забезпечення конституційності рівності прав та інтересів суб'єктів суспільних відносин встановлюється варіативність способів реалізації права. Захист же відбувається через обов'язковість відпочинку та його тривалості за рівної тривалості навантаження. Проте, усвідомлюючи можливість зловживання такою можливістю як роботодавцем через примушування до погодження, так і працівником задля отримання більшої заробітної плати, законодавство забезпечує право на відпочинок через критерії. Аналіз таких критеріїв визначає їх ключову особливість щодо перевищення інтересів суспільства або трудового колективу над інтересами однієї особи.

Відповідно до ст. 136 Трудового кодексу Польщі для праці щодо нагляду за технічними пристроями, які лише частково готові до роботи, може бути дозволено щоденне продовження робочого часу, однак не більше ніж на 16 годин за розрахунковий період не більше 1 місяця. За кожен продовжений щоденний робочий час працівнику надається відпочинок у часі, що відповідає принаймні кількості відпрацьованих годин [2]. Отже, можна дійти висновку, що принцип відновлюваності лежить в основі всього правового регулювання конституційного права на відпочинок, отже, більш доцільним є встановлення його на рівні конституції, що дасть змогу охопити всі випадки скорочення часу відпочинку. Також особливістю врегулювання права на відпочинок саме у Польщі є визначення спеціальних норм не в окремих підзаконних актах, а у загальному порядку. Це дає змогу уникнути колізій щодо ієрархічності, а також захистити права осіб, що працюють за окремими напрямами. Вимога щодо 16 годин на місяць $є$ фактично максимальною нормою перепрацювання. Ця норма є яскравим прикладом поєднання норм права 3 різних галузей, оскільки конституційне право на відпочинок поєднується з фінансовими норми щодо звітностей та виплат.

На основі проведеного аналізу нормативно-правових актів, що регулюють втілення конституційного права на відпочинок у Польщі, можна виділити такі його особливості.

1) Диференційованість. Ця особливість полягає в конституційному врегулюванні не лише права на відпочинок як загального, але й встановлення його видів залежно від тривалості, суб' єктів та призначення відпустки. Внаслідок використання такого способу вже на рівні законодавства обсяг права на відпочинок не може бути зменшений, тому виникає обов'язок у врегулюванні відносин, адже наявність прогалин щодо певних видів одразу буде помітною. Також диференційованість розкривається через різні напрями забезпечення права на відпочинок, що здійснюються як шляхом гарантування, так і через передбачення заборон.

2) Відплатність. Здійснивши аналіз конституційних норм, розуміємо, що право на відпочинок не належить до таких прав, які неможливо обмежити. Проте його нерозривний зв'язок з особистими та невід'ємними конституційними правами зобов'язує здійснювати дії щодо мінімізації негативних наслідків. У польському законодавстві таких шляхів декілька. Щодо першого, 
то він полягає в матеріальному відшкодуванні або оплаті понаднормових годин. Слід зазначити, що схожі методи застосовуються в національному законодавстві, проте на рівні конституції вони не закріплені. Щодо наступного шляху, то він $є$ новелою для саме для українського законодавства, а його сутність полягає в наданні відпочинку такої ж тривалості, що й тривалість виконання професійних обов'язків понаднормово. Таким чином, особа, що працює, має час як на відновлення сил, так і на реалізацію тих справ, що були відкладені внаслідок термінового виконання обов'язків.

3) Державне забезпечення. Звертаючись до норм Конституції Польщі щодо права на відпочинок, помічаємо обов'язкову наявність обов'язку держави щодо сприяння його реалізації або охороні здійснення, що особливо яскраво проявляється в праві на відпустку для батьків. Крім того, державне забезпечення полягає у встановленні спеціальних норм щодо права на відпочинок в умовах понаднормової роботи. Державне забезпечення відбувається в усіх конституційних напрямах, тобто щодо ведення соціальної політики та гарантування відповідних соціальних відпусток; щодо розвитку економіки, отже, забезпечення можливості держави компенсувати втрачений відпочинок через роботу щодо подолання форс-мажорних обставин. На рівні вже законодавчих актів законодавче забезпечення проявляється через встановлення обмежень та критеріїв, за допомогою яких значно простіше з'ясовувати, чи був дотриманий порядок реалізації права на відпочинок суб'єктами.

Висновки. Враховуючи позитивні зміни в польському законодавстві, доходимо висновку про потребу вдосконалення національного законодавства. Запозичення має відбуватися щодо встановлення більшого переліку видів права на відпочинок на рівні саме Конституції. Слід наголосити на тому, що не обов'язковим є їх об'єднання в межах однієї норми, адже для кращого втілення права на відпочинок необхідним $є$ його поєднання з іншими конституційними правами, що відображають призначення такого відпочинку. Отже, ч. 1 ст. 45 Конституції України варто подати в такій редакції: «працівник має право на відпочинок у формі щорічних відпусток та додаткових відпусток, щотижневого безперервного відпочинку та щоденного безперервного відпочинку. Відпочинок у святкові та вихідні дні забезпечується Кабінетом Міністрів України». Також ст. 46 Конституції України варто доповнити ч. 3, відповідно до якої «кожен, хто працює, має право на соціальну відпустку у разі настання передбачених законом випадків. Держава зобов'язана гарантувати реалізацію права на соціальні відпустки». Такі конституційні зміни допомагають зробити реалізацію права на відпочинок більш конкретною та зрозуміти, які завдання стоять перед кожним конкретним органом влади. Так, Кабінет Міністрів зобов'язаний здійснювати нагляд і контроль над втіленням права на відпочинок. Водночас для забезпечення соціальних відпусток як особливого виду права на відпочинок встановлюється значно більше право держави на втручання в суспільні відносини, отже, використання інших методів. Закріплення таких положень на конституційному рівні робить їх правовими та усуває потребу у постійному підтвердженні з боку Конституційного суду щодо відповідності нормам чи судам загальної юрисдикції правомірності дій державних органів.

\section{Список використаних джерел:}

1. Шаповал В.М. Конституція Польської Республіки (з передмовою Володимира Шаповала). Київ : Москаленко О.М., 2018. 84 с.

2. Kodeks pracy: Ustava z dnia 26 czerwca 1974 r. Dz. U. $1974 \mathrm{Nr} 24$ poz. 141. URL: https: cutt.ly/drSCQQq (дата звернення: 19.12.2019). 